\title{
Teacher Motivation as a Factor in Language Teaching and Learning in Nigeria
}

Nkechi M. Christopher

\begin{abstract}
A survey was carried out to investigate the level of teacher motivation, the association between teacher motivation and language learning and teaching, as well as the factors that could impact on them in two states in the Nigeria federation. This study became necessary in order to assess the impact that government efforts, particularly the use of salary incentives, have made in restoring standards in the school system. The view is held that there has been no commensurate improvement in student performance in response to government's gesture. However, this study indicates that most teachers are more intrinsically than extrinsically motivated in their exhibition of commendable classroom behaviours. Teachers' claim that they are not motivated to teach is supported by negative assessment of several variables in the teaching/learning environment that are critical in raising and maintaining teacher motivation, teaching efficiency and effective language learning.
\end{abstract}

Key words: Language Learning, Student Performance, Teacher Efficacy, Teacher Motivation

\section{Introduction}

Teacher motivation is of utmost importance in ensuring that the time spent in school is beneficial to students and fulfilling to teachers, especially in a lacklustre environment. In situations where the home and school environments do not provide the atmosphere and features that spur and support the gratification of curiosity and inquisitiveness, students may attend school without being able to exploit opportunities available for learning to the maximum without teacher support. The teacher's role therefore should not be limited to the teaching of subject matters, but teaching in ways that make learners want to learn.

In Nigeria, teachers' roles in students' lives were well recognised before the 1980s, and teachers were seen as disciplinarians that helped parents guide children on their path to becoming responsible adults. Nonetheless, teachers have somewhat always been the butt of Nigerian society's jokes, especially on the issue of low wages; but they were all the same venerated as character moulders, so much so that they constantly received gifts from parents. They were, however, to be further debased during a prolonged general economic hardship due to non-payment of salaries over long periods. They became the ridicule of society and their students as well. It is obvious from Achimugu's (2005) catalogue of teachers' agonies that few teachers are in the profession for the love of it rather 
than for lack of alternatives. Moreover, the loss of the thirst for knowledge, now reduced to certification attainment, implies that dedication to learning has waned. By implication, teacher motivation is of utmost importance in the restoration and sustenance standards.

Recognising waning teacher motivation, and to resuscitate the education sector in order to meet the demands of Education for All and achieve the Millennium Development Goals (MDG targets), since 2001 federal and state governments embarked on various programmes to restore lost glories of yesteryears. The governments have indulged to various extents on school infrastructure upgrade, class size reduction and school rationalisation for easy administration, salary increase and advancement of car loans to teachers, inservice training, institution of awards, and professionalisation of teaching. It needs be ascertained that these are far-reaching measures. The relevance of this study is in its investigation of the extent to which teachers have been motivated, and the presentation of empirical evidence that indicates why government efforts on teacher motivation may not have sufficiently impacted student outcome to the extent and with the urgency expected.

\section{Literature review}

According to Glatthorn (1995, p. 42), motivation "refers to the strength of the inner drive to achieve professional goals." Motivation stimulates appropriate behaviour (Ofoegbu, 2004) required to ensure that teachers perform their duties (Davidson, 2007). Teacher motivation reflects in a teacher's attitude to teaching activities and related behaviour (Ofoegbu, Yong, 2004, Kocabas, 2009), and can influence students' belief and attitude (Debnath, Tandon \& Pointer, 2007), thereby determining whether students would like or dislike education (Czubaj, 1996). While teachers with low motivation would likely produce low quality students (Mertler, 2002), those with high motivation cultivate a determination that enables them to motivate non-intrinsically motivated students to learn, even in challenging situations (Alderman, 2004; Mendler, 2001).

Dedication to duty and willingness to continue in the profession would be determined by how satisfied teachers are with the work itself and surrounding factors that make it easy or difficult to accomplish tasks. According to Davidson (2007), writing about Tanzanian situation, teacher motivation is mostly "linked to how teachers feel they are being treated and to the way they perceive their own working and living conditions." Similar perception determines career commitment among teachers in Brunei (Yong, 1999). According to Yong, teacher motivation and career commitment are among the most important factors that affect school effectiveness. Low morale among teachers has negative implications for student learning and teachers' health (Mertler, 2002; Moloi \& Bush, 2006).

Some of the issues that caused dissatisfaction among Tanzanian teachers, according to Davidson (2007), were: mismatch of salary with important needs, inability to send children to school, poor living conditions, and limited access to health care. However, Yong (1999) found that the main reason 
for disenchantment among some Brunei teachers was that the job was "too stressful" or "too demanding." Nonetheless, among the Brunei teachers some were committed to the job because they loved working with children and desired to impart knowledge.

In essence, teacher motivation can be intrinsically and extrinsically induced and sustained. According Ofoegbu (2004) intrinsic motivation is necessary for the teacher to teach effectively, and is the "what of change;" while extrinsic motivation is the "how of change," engendered for the purpose of school improvement through giving incentive for work done. An example of extrinsic motivation is the performancebased award introduced in Kentucky and Charlotte-Mecklenburg School District (US) (Kelly et al., 2002) which saw student performance improve as teachers worked towards obtaining promised awards. Award for good work increases motivation. Nevertheless, Performance Pay (2004, p. 18) quotes William J. Slotnik as saying that "Pay for Performance is neither a silver bullet nor a magic wand."

Extrinsically driven teacher motivation aims to make teachers happy, satisfied, dedicated and committed to bringing out their best in their places of work (Ofoegbu, 2004). Monetary reward is a major means of increasing worker motivation, and poor pay is the bane of the teaching profession in many situations. "Pay is a measure of teacher worth" (Yong, 1999). Irregular payment (UNESCO, 2006), deductions from pay and delayed promotion (Achimugu, 2005; Davidson, 2007) erode motivation. Menon and Saitis (2006) found that while the Greek teachers they studied were happy with the job itself they were not with their pay.
Various extrinsic motivating factors can be initiated or manipulated to increase different aspects of teacher motivation, for example:

- Deliberate administrative effort through performance incentives (Mertler, 2002; Bright futures for exceptional learners, 2000; Kelley \& Finnigan, 2003), infrastructure and positive atmosphere can be used to increase teacher satisfaction (Czubaj, 1996).

- Supportive environment drives up motivation, causing the release of teacher quality and energy for positive growth of teacher, learner and school (Glatthorn, 1995; Davidson, 2007). Physical environment is also crucial (UNESCO, 2006; Moloi \& Bush, 2006) - overcrowded classrooms, poor supply of teaching and learning materials, dilapidated buildings (or no building), and too many teaching periods/ subjects (Davidson, 2007; Yong, 1999; Achimugu, 2005) do not help teacher motivation.

- Positive feedback from student performance and from administrators and supervisors increase motivation (Glatthorn, 1995), while loss of public respect could puncture it (Achimugu, 2005; Yong, 1999).

- Collegiality increases morale (Czubaj, 1996). Team teaching creates learning opportunities and allows teachers to share negative and positive experiences (Glatthorn, 1995; Spies, 2003).

Each potential source of motivation would have different impact on teachers due to individual differences (Kocabas, 2009) 
Table 1: Profile of study respondents

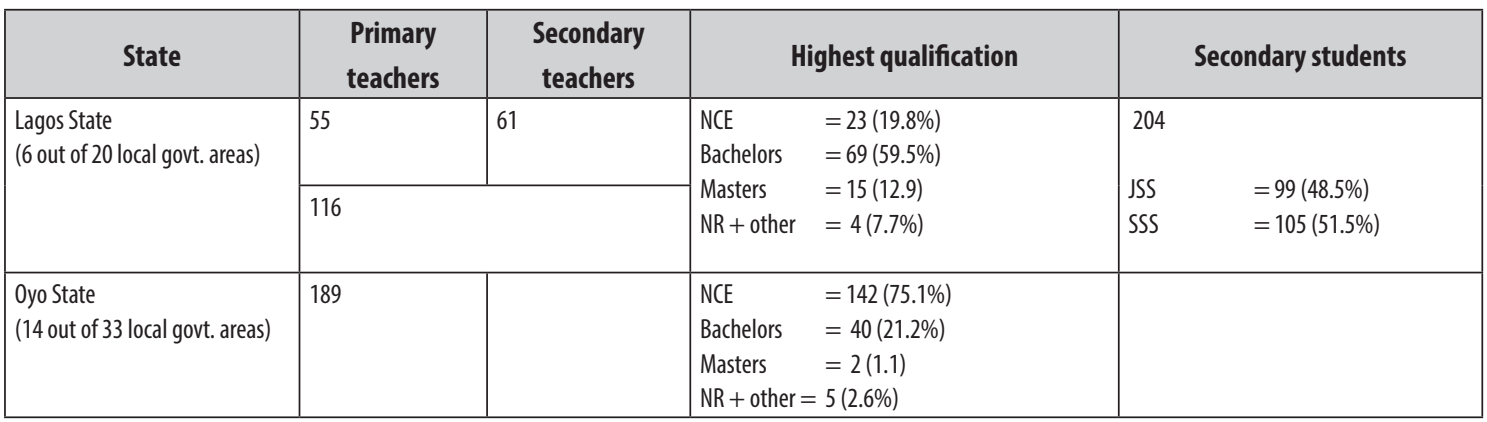

in beliefs and expectation (Clark, 1994). Therefore, an ideal situation is one that allows teachers to find reasons to continue to put in their best in helping learners to learn.

Teacher motivation influences classroom practice and both of these influence students' belief and attitude, and thus teacher motivation level can enhance or weaken student performance (Ofoegbu, 2004; Debnath, Tandon \& Pointer, 2007). Mertler (2002), Moloi and Bush (2003) and Kocabas (2009) posit that dissatisfied teachers will most likely produce low quality students. This is what is suggested by Ahimugu's (2005) paintings of Nigerian teachers, as the blurb to his book reflects: "An average Nigerian teacher is politically harassed, socially assaulted, financially humiliated, professionally handicapped, psychologically depressed, emotionally traumatised and morally frustrated." This acerbic summation runs counter to government's "utopian policies," which reads in part: to "encourage the spirit of enquiry and creativity in teachers; help teachers fit into the social life of the community and society at large" (Achimugu, p.55).

Achimugu's (2005) assessment teachers' situation prior to the introduction of changes provides a good basis for evaluating progress made so far to increase teacher motivation among teachers in the states studied. These questions guide the presentation and discussion of results of analysed data:

1. How much of the teacher workforce is motivated?

2. What are teachers' perceptions on variables that are instrumental in teacher motivation?

3. What relationship exists between teacher efficacy and motivation of students to learn?

4. What is the relationship between teacher motivation and student performance?

\section{Methodology}

In this descriptive survey, data were generated by means of questionnaires administered to teachers and students of public schools in two states (Lagos and Oyo Sates) in the southwest zone (Nigeria has six geopolitical zones). The first set of teacher questionnaire and a student questionnaire were administered to primary and secondary school teachers as well as secondary school students in Lagos State in the first quarter of 2010 through personal contact. The teacher 
Table 2: Teachers' assessment of payment and promotion adequacy (\%)

\begin{tabular}{|l|l|l|l|l|}
\hline & \multicolumn{3}{|c|}{ Agree } & \multicolumn{2}{c|}{ Disagree } \\
\hline & Lagos & Oyo & Lagos & Oyo \\
\hline My salary is adequate & 29.2 & 9.5 & 58.4 & 83.6 \\
\hline My salary is paid regularly & 63.1 & 32.1 & 28.8 & 54.9 \\
\hline Ireceive my promotion whenever it is due & 44.6 & 12.1 & 48.5 & 76.9 \\
\hline
\end{tabular}

*Difference between "Agree" \& "Disagree" = "Don't know" response

questionnaire was slightly revised by dropping a few items and administered to primary school teachers (only) in Oyo State during a training workshop in the fourth quarter of 2010. While it is expected that the secondary school teachers are English subject teachers, a few primary teachers may not necessarily have trained to teach English - subject specialisation is yet to be achieved in Nigerian primary schools. The return rates are high, almost 100\% for students and over $95 \%$ for teachers in the first state, and $85 \%$ in the second state (workshop). Table 1 shows an analysis of the study respondents.

In Lagos, teachers were drawn from 34 schools - 15 primary schools, 11 junior secondary schools (JSS) and eight senior secondary schools (SSS); and students from 11 JSS and 10 SSS schools. The Oyo teachers came from well over 160 primary schools. The highest teacher qualification was Masters Degree and there were two holders in primary schools in each state, where predominant highest qualification was National Certificate of Education (NCE). There however were Bachelors Degree holders in primary schools in both states, as well as four NCE (and 4 other) in the secondary schools.

For easy response, close-ended 3-5 points Likert's scaled items were grouped so respondents could indicate 1) the extent to which they agreed with a statement, or 2) how much a statement was true of them/ their case and 3) the adequacy of situations or resources in the school environment. Since experience has shown that people generally ignore open-ended items these were very minimal; for example, out of 116 teachers in Lagos only two responded to the question: "At the end of the session students should be able to do what tasks using English? Please list."

The data collected were subjected to descriptive statistical analysis, and the percentages of positive or desirable options are presented in tables. Although trends in the manifestation of indicators are

Table 3: Teacher assessment of administrative actions

\begin{tabular}{|l|l|l|l|}
\hline \multicolumn{1}{|c|}{ Category } & \multicolumn{1}{|c|}{ Indicators } & \multicolumn{1}{c|}{ Lagos } & \multicolumn{1}{c|}{ Oyo } \\
\hline Professional development & I will be allowed to go for further studies & 76.2 & 83.3 \\
\cline { 2 - 5 } & I know where I can get more training & 68.6 & 43.5 \\
\cline { 2 - 5 } & The Min of Education provides in-service training & 59.1 & 69.3 \\
\cline { 2 - 5 } & I attend conferences, workshops and seminars on ELT & 53.6 & 59.0 \\
\hline Administration & Regular visits \& supervision by inspectors/supervisors & 78.3 & 89.3 \\
\cline { 2 - 5 } & MOE/SUBEB response to needs & 33.3 & 52.3 \\
\cline { 2 - 5 } & Discipline in school & 69.8 & \\
\hline
\end{tabular}


similar for both states, actual extents differ; consequently, data for the two states are presented side by side for easy comparison.

\section{Data analysis and discussion}

Results of data analysis for Lagos and Oyo States suggest similar trends but considerable difference in variables manifestations. Therefore, results for the two states are presented side by side, while differentiation between primary and secondary teachers' data is only applied where secondary students' data are also used.

\section{Motivated teacher workforce}

Contrary to the thinking of education managers, most teachers in the study disagree $($ Lagos $=62.5 \%$; Oyo $=52.5 \%)$ that teachers are adequately motivated to teach. Only $22.3 \%$ of Lagos teachers and $40.2 \%$ of Oyo teachers accept that they are motivated to teach. Nonetheless, $81.3 \%$ of Lagos and $98.9 \%$ of Oyo teachers are "Happy to continue teaching," suggesting that intrinsic motivation may prevail where external factors fail in the drive to improve student performance. The higher figures recorded for Oyo over Lagos teachers runs contrary to expectation, considering the backgrounds of these states. While Lagos State teachers enjoyed higher pay, the Oyo State teachers had a running battle with the state governor for almost two years on salary issues by the time of data collection. The explanation for the apparent inverse association between pay and teacher motivation in this study may be provided by some other study findings.

Teachers' perceptions on factors that contribute to teacher motivation

Achimugu (2005) had observed that "Nigerian teachers are among the worst paid in the world" (p.41), further noting that "his salary is delayed; for the arrears, he has to smell it when he gets to heaven. The teacher is like a church rat" (p.36) and had to borrow from peasants. Table 2 shows teachers' view on adequacy of salary, promptness of its payment and promotion.

Oyo teachers trail terribly behind their Lagos counterparts on positive assessment of three important salary issues raised in the study. It is therefore quite interesting that the Oyo teachers still indicated higher level of motivation than their Lagos

Table 4: Teachers' assessment of environmental factors (\%)

\begin{tabular}{|l|l|l|l|}
\hline \multicolumn{1}{|c|}{ Category } & \multicolumn{1}{|c|}{ Indicators } & \multicolumn{1}{c|}{ Lagos } & \multicolumn{1}{c|}{ Oyo } \\
\hline \multirow{3}{*}{ Workload } & Students are not too many for me & 24.8 & 75.7 \\
\cline { 2 - 4 } & My workload is just ok & 52.3 & 64.8 \\
\hline \multirow{5}{*}{ Physical environment } & Classroom is conducive & 16.4 & 26.5 \\
\cline { 2 - 4 } & Classroom arrangement, space \& furniture & 38.6 & 48.2 \\
\cline { 2 - 4 } & Convenience & 39.6 & 36.6 \\
\hline \multirow{5}{*}{ Resources availability } & Library for learners (Sec schl = 31.6\%) & 38.0 & 41.0 \\
\cline { 2 - 4 } & Teacher has material for teaching & 21.5 & 28.2 \\
\cline { 2 - 4 } & Availability of books for teachers (Sec schl. =42.8\%) & 43.2 & 41.2 \\
\cline { 2 - 4 } & Availability of books for learners (Sec schl. =55\%) & 58.0 & 44.6 \\
\cline { 2 - 4 } & Budget for ELT & 36.0 & 36.0 \\
\hline
\end{tabular}


Table 5: Teachers' assessment of response from students and colleagues

\begin{tabular}{|l|l|l|l|}
\hline \multicolumn{1}{|c|}{ Category } & & \multicolumn{1}{c|}{ Lagos } & \multicolumn{1}{c|}{ Oyo } \\
\hline \multirow{2}{*}{ Student behaviour } & I am encouraged to teach by the way students respond in class & 50.5 & 66.9 \\
\cline { 2 - 5 } & Discipline among learners, e.g. do assignment, paying attention in class & 50.0 & 58.8 \\
\hline Collegiality & Collegiality (regular discussion on ELT) & 38.8 & 43.3 \\
\hline
\end{tabular}

counterparts. Apparently, although salary is a measure of a teacher's worth (Yong, 1999), this finding imply that other factors must also be important in provoking more dedication and efficiency from teachers. Tables 3-5 show percentages of teachers that positively rated some other variables known to contribute to teacher motivation. Table 3 shows percentages of teachers that positively rated indicators on the availability of opportunities for professional development and growth as well as roles played by education administrators.

Professional development can increase teacher efficacy, and where certified, leads to promotion. The first item on the table suggests that both states make room for teachers to go for certificate awarding professional development, and this is confirmed by other study finding which reveals that of 116 who had spent 21-34 years on the job, 115 received their highest qualification $0-20$ years ago. Most of the few that were not sure that they would be allowed to go for further training also did not know where to look to for more training (item b) or had not sought for.

Further, since signing into Education for All agenda, and in view of poor academic achievement among students, federal and state governments (in conjunction with international agencies) had been organising training programmes for teachers. The results in the table (item c) confirm the availability of such programmes, but suggest that not all teachers had been able to access them. Similarly, the numbers of teachers attending conferences and workshops are low (item d); this being an area yet to be developed in ways that would attract school teachers. ELT conferences are usually scholarly affairs among higher education teachers and have not addressed the need for professional development of teachers at lower levels.

Another factor that can sustain teacher motivation is the role of school administration from outside and from within the school. Teachers in both states indicated that the level of administrative and supervisory visits was commendable (item e) but that the needs expressed to the management bodies were not adequately responded to; more so in Lagos than in Oyo State (item f). However, on within-school administration, $80.2 \%$ of Lagos teachers and $88.8 \%$ of Oyo teachers considered general school discipline adequate. Item $\mathrm{g}$ suggests that school discipline was commendable in both states. It seems that the unsavoury incidences of teachers being beaten up and harassed by students and their parents alike (Achimugu, 2005) may have reduced significantly.

Of all the 7 items on Table 3, Lagos exceeds Oyo teachers only in one (b). If these variables, as well as those in Table 4 (below), contribute to teacher motivation, then it is possible that they could account for some differences in levels of motivation between the two states. Table 4 displays variables in 
Table 6: Teacher efficacy assessment

\begin{tabular}{|l|l|l|}
\hline & \multicolumn{1}{|c|}{ Lagos } & \multicolumn{1}{|c|}{ Oyo } \\
\hline Adequacy of training & 88.7 & 97.3 \\
\hline Need more training to teach better & 77.7 & 92.3 \\
\hline Curriculum has not advanced beyond training & 77.4 & - \\
\hline Understand students'learning needs & 83.3 & 77.7 \\
\hline Use student performance to judge effectiveness & 78.1 & 94.0 \\
\hline Reflect on teaching regularly & 91.2 & 97.7 \\
\hline Feel incapable when learners don't perform well & 56.4 & - \\
\hline
\end{tabular}

three categories: teacher workload, physical environment of learning and resources availability.

The only impressive figures in Table 4 occur in the teacher workload category, with Oyo situation looking better than that of Lagos. This can easily be explained by the fact that Oyo State had rationalised its schools into manageable school and class units, while Lagos State was just beginning the process. While primary class population in Oyo State was within 30 pupils per class, some Lagos State secondary classes, especially at the junior secondary level were well over 100.

Additionally, in terms of physical environment, teachers assessment suggest a demoralising work environment in both states (Oyo is slightly better). Lagos still had similar scenario described by Achimugu (2005), that a classroom designed for 30 students in 1960s was now being used for 96 pupils. Although some improvement may have been made since the time of Achimugu's publication, it is worth mentioning that in addition to overcrowding, some classrooms not only lacked furniture, but were also dilapidated. Under such condition, it is no surprise that many schools either did not have libraries or a functional one (item $\mathrm{f}$ ). The situation may be worse than the data on the table suggest; for example, while $31.6 \%$ of Lagos secondary school teachers indicated that a school library existed only $17.6 \%$ of students in the study so indicated.

Similarly, there is difference in teachers' and students' perception/rating of book availability among each group, with the one overrating the other. Whereas $42.8 \%$ secondary school teachers indicated that they had adequate books, $64.7 \%$ of students believed they did. On the other hand, $29.9 \%$ of students indicated that they had books, while $55 \%$ of teacher thought they did. Student belief about teacher access to teaching resources could impact on students' perception of teacher

Table 7: Students' perception of teachers' behaviour that can motivate learning (Lagos, secondary school students)

\begin{tabular}{|l|l|l|l|}
\hline \multicolumn{1}{|c|}{ Item } & \multicolumn{1}{c|}{ Not true } & \multicolumn{1}{c|}{ Somewhat true } & \multicolumn{1}{c|}{ True } \\
\hline My teacher teaches English well & 1.0 & 4.4 & 94.6 \\
\hline Teacher allows imagination/creativity & 2.0 & 6.4 & 91.7 \\
\hline Teacher makes student feel important & 3.4 & 13.2 & 83.3 \\
\hline Teacher gives support & 3.0 & 15.8 & 81.3 \\
\hline Teacher gives encouraging words & 10.9 & 12.9 & 76.1 \\
\hline Teacher allows student control & 12.7 & 22.1 & 65.2 \\
\hline Teacher is not too concerned with marks & 25.1 & 19.7 & 55.2 \\
\hline Teacher is not partial to the intelligent & 36.0 & 20.8 & 43.1 \\
\hline
\end{tabular}


Table 8: Teacher assessment of student learning outcome (percentage of teachers)

\begin{tabular}{|l|l|l|}
\hline \multirow{3}{*}{ Learning Outcome } & Learnt enough & 56.2 \\
\cline { 2 - 3 } & Need more effort outside school & 41.1 \\
\cline { 2 - 3 } & Not done enough & 2.7 \\
\cline { 2 - 3 } & Total & 100.0 \\
\hline
\end{tabular}

credibility, with possible effect on student motivation to learn. On the other hand, misalignment between teacher perception of students' access to books and actual access could create perceptual problems for teachers that may impact on how students are regarded and treated when they fail to meet expectations on assignment and performance.

In spite of much ado about free education and free textbooks, the data in the table suggest that after nine years of UBE (universal basic education) many students did not have books. Governments do not supply adequate books and materials for teaching and learning (items g-i). A bookand literacy-unfriendly environment can neither support effective language learning nor increase teacher and student motivation to teach and learn in enthusiastic ways that will yield desired outcome. Positive outcome begets positive effort.

Teachers need to see and believe that their students respect them and value their effort in order to be positively motivated to help students to learn. Table 5 shows that only half of the Lagos teachers assessed response from their students as encouraging (Oyo $=66.9 \%)$. Related to this is individual student discipline, which was also more discouraging in Lagos than Oyo State.

Perhaps if there is a high level of collegiality among teachers, they would have avenues for productive discussion of issues and problem in their ELT experience. Contrarily, less than half of teachers in each state indulged in regular ELT discussion with their colleagues (Table 5). Lack of interaction among subject teachers is suggestive of low-level team teaching and sharing of professional experience, which may partly be occasioned by limited number of subject teachers in each school. Moreover, active ELT associations and forums are needed to create avenues for in-service teacher development and interactions.

\section{Relationship between teacher efficacy and motivation of students to learn}

High efficacy teachers, according to Alderman (2004), feel good about themselves, their teaching and their students; they are also innovative in their practice (Glatthorn, 1995). Since this study establishes that very significant percentage of the teachers is happy to continue teaching, Table 6 shows teachers' ratings

Table 9: Relationship between teacher motivation and student performance

\begin{tabular}{|l|l|l|}
\hline & \multicolumn{1}{|c|}{ Lagos } & \multicolumn{1}{|c|}{ Oyo } \\
\hline $\begin{array}{l}\text { Extrinsic motivation: } \\
\text { "Teachers are well motivated to teach" }\end{array}$ & & $40.2 \%$ \\
\hline Salary index & $22.3 \%$ & 6.2 \\
\cline { 2 - 3 } Intrinsic motivation: "I am happy to continue teaching" & 8.4 & $98.9 \%$ \\
\hline "I am happy with my students' performance" & $81.3 \%$ & $77.7 \%$ \\
\hline
\end{tabular}


of other variables that indicate teacher efficacy. Also shown on the table are items that allow an evaluation of teacher efficacy.

Items $\mathrm{a}-\mathrm{d}$ in Table 6 are indicative of teachers' belief of their ability to execute their practice creditably. In terms of (a), 89$97 \%$ of the teachers in the study are certain that "My training prepared me adequately for teaching English." Nonetheless, they found that they still needed more training to teach better (item b), even though the Lagos teachers did not assess the curriculum as having advanced beyond their training (item c). These findings suggest that most teachers in both states can be placed in the high efficacy bracket, since individual teachers held "I can" and "I will" beliefs, and claimed that they understood their students' learning needs (item d). Items e-f suggest that the teachers applied their beliefs in their practice, with the result that $56.4 \%$ of Lagos teachers (item g) "Feel incapable when learners don't perform well." In essence, this set of teachers evaluated themselves against their beliefs using students' performance. Further, Table 7 summarises students' perception of teachers' classroom behaviour that reflect teacher qualities.

Interestingly, despite consistent recurrent poor student performance in national examinations, $94.6 \%$ of 202 students in the study believed that their teachers taught English well (item a). Students' favourable perception of their teachers' classroom behaviours in b-e suggests that teachers motivated their students to learn English. However, power sharing between teachers and students (item f) is low, which may discourage optimum student involvement in the teaching process. On the hand, the assessment of items $g$ and $h$ may suggest that some teachers were not able to carry along those that did not show sufficient level of proficiency in English.

\section{Relation between teacher motivation and student performance}

Year after year woeful national examination results raised concern about the wellbeing of the education system. Can teacher motivation give insight to why students perform poorly? Data presented so far indicate that while most teachers may be intrinsically motivated, factors in the education context had not improved sufficiently to drive teacher motivation and improved student performance.

Table 8 shows teachers' confidence level, indicating that only $56.2 \%$ of teachers considered their students as generally having learnt enough during a school year. Confidence level drops at the senior secondary level - only 11 out of 28 teachers perceived their students as having learnt enough. While, no doubt, all students need to put in "more effort outside school," most did not have the avenue for doing so. Indeed, many students may not have seen the need to do so $-86.7 \%$ of students were confident of their communicative competence skills, and $61-68 \%$ indicated that they had no problems in putting their skills to use in performing language tasks, such as writing correct sentences and reading textbooks. Meanwhile, half of the secondary school teachers in the study were not happy with their students' performance.

Table 9 displays, for comparison, teachers' motivation levels and their satisfaction with their students' performance.

Factors that support teacher motivation 
were low, more so in Lagos than in Oyo State, probably accounting for teachers' feeling that they were not well motivated to teach. Further, this study confirms that whereas salary incentives are important in teacher motivation, they are not capable of transcending or compensating for demotivating factors in the teaching and learning environment. Taken together, the data on Table 9 suggest that student performance correlated with motivation level, but that it was not determined so much by how much salary teachers were paid as much as it was by other extrinsic factors of motivation.

\section{Conclusion}

The study has shown that teacher motivation level could predict student performance, as indicated in literature, and as governments in Nigeria already know. However, while state governments felt that they had put in enough effort to increase teacher motivation, the study findings indicate that whereas adequate salary is important, many issues relevant to teacher motivation may have been underestimated. Moreover, many factors that contribute to teacher motivation and that are also important for student learning have been adjudged as inadequate, as summarised below:

\begin{tabular}{l|l}
\hline \multicolumn{1}{c|}{ Motivation variable } & \multicolumn{1}{c}{ Assessment } \\
\hline Teachers motivated & $22-40 \%$ \\
\hline Salary and promotion & Very Poor/Poor \\
\hline Training & Fair \\
\hline Administration (supervision) & Fair \\
\hline Administration (response) & Poor \\
\hline Parental support & Very Poor \\
\hline Resource availability \& provision & Poor \\
\hline Physical environment & Poor \\
\hline Workload (50-65\% are coping) & Fair \\
\hline
\end{tabular}

It can be deduced from the study that teachers were driven mostly by intrinsic motivation, but that this was inadequate to engender efficient teaching or effective learning. This assertion and the study findings equally apply to other states in Nigeria, as this excerpt insinuates:

My office is under the tree, likewise the seven teachers we have here. We don't have tables and desks. These children are meant to sit anyhow and anywhere while classes are taken. We have been like this since last year and I do not know for how long we will continue this way. (A headteacher in Enugu State [Njoku, The Guardian, 2011, p.2])

Fortunately, as many other systems in Nigerian society, neither the teachers nor students had really lost hope in the school system, since students had faith in their teachers' ability to teach them. Nonetheless, to improve the teaching and learning of English in Nigeria, a lot needs to be done to create a supportive environment that will motivate both teachers and learners to work towards achieving desired outcome; bearing in mind that the English language is foundational to learning and performing well in all other school subjects.

Further, the findings of this study underscore the importance of backing and evaluating government policies with research findings. The indication is that education managers' assumptions about teachers and the education system need to be validated through research. In this process, the involvement of teachers in making decisions that concern them, their practice and the welfare of the entire education system is inevitable, even if this would require both sides to undergo a learning process initially. Teachers should 
be involved in planning development and changes, as their participation tend to boost teacher motivation.

\section{About the author}

Nkechi M. Christopher, PhD., is a member of IATEFL, ELTAN, IRA, South-West Coordinator (2006-2008) Reading Association of Nigeria(RAN) and Consultant on English Language Teaching, British Council (Nigeria). She is a Senior Lecturer in the Department of Communication and Language Arts, University of Ibadan, Nigeria. She has published articles in books, local and international journals on English language learning and assessment, as well as on literacy and book publishing in Nigeria. The author can be reached at nmxtopher@gmail.com

\section{References}

Achimugu, L. (2005). The agonies of Nigerian teachers. Ibadan: Heinemann Educational Books.

Alderman, M. K. (2004). Motivation for achievement: Possibilities for teaching and learning (2nd edn.). Mahwah, NJ: Lawrence Erlbaum Associates.

Bright Futures for Exceptional Learners. (2000, July/August). Teaching Exceptional Children, 32, 56+. Retrieved January 10, 2012, from Questia database: http://www.questia.com/ PM.qst? $a=0 \& d=5035445190$.

Clark, R. E. (1994). Assessment of distance learning technology. In E. L. Baker \& H. F. O’Neil (Eds.). Technology assessment in education and training (pp.63-78). Hillsdale, NJ: Lawrence Erlbaum Associates.

Czubaj, C. A. (1996). Maintaining teacher motivation. Education, 116(3), 372-378. Retrieved January 8, 2012, from Questia database: http://www.questia.com/ PM.qst? $\mathrm{a}=\mathrm{o} \& \mathrm{~d}=5000367863$

Davidson, E. (2007). The pivotal role of teacher motivation in Tanzanian education. The educational forum, 71(2), 157-166. Retrieved January 8, 2012, from Questia database: http:// www.questia.com/PM.qst?a $=0 \& d=5035109024$

Debnath, S. C. Tandon, S. \& Pointer, L. V. (2007). Designing business school courses to promote student motivation: An application of the job characteristics model. Journal of management education, 31, 812-831

Glatthorn, A. (1995). Teacher development. In L.
W. Anderson (Ed.) International encyclopedia of teaching and teacher education (pp. 41-46), New York: Pergamon.

Kelley, C. J. \& Finnigan, K. (2003). The effects of organizational context on teacher expectancy. Educational administration quarterly, 39, 603634.

Kocabas, I. (2009). The effects of sources of motivation on teachers' motivation levels. Education, 129(4), 724-733.

Mendler, A. N. (2001). Connecting with students. Alexandria, VA: ASCD.

Menon, M. E. \& Saitis, C. (2006). Satisfaction of pre-service and in-service teachers with primary school organization: Evidence from Greece. Educational management administration \& leadership, 34, 345-363.

Mertler, C. A. (2002). Job satisfaction and perception of motivation among middle and high school teachers. American secondary education, 31(1), 43-53.

Moloi, K. \& Bush, T. (2006). An overview of education management in South Africa. Management in education, 20, 15-22.

Njoku, L. (February 20, 2011). In Enugu, pupils study under tress as neglect cripples primary education. The Guardian, p.2.

Ofoegbu, F. (2004). Teacher motivation: A factor for classroom effectiveness and school improvement in Nigeria. College student journal, 38(1), 81-88.

Performance Pay. (2004). ASEE Prism, 13, 18. Retrieved January 11, 2012, from Questia database: http://www.questia.com/ PM.qst? $\mathrm{a}=\mathrm{o} \& \mathrm{~d}=5037551036$.

Spies, P. (2003). Promised land or assembly line? Journal of staff development, 24(3), 57-62.

UNESCO. (2006). Teacher motivation, compensation and working conditions. Guidebook for planning education in emergencies and reconstruction, Paris: International Institute for Education Planning (IIEP)

Yong, B. C. (1999). The career commitment of primary teachers in Brunei Darussalam: Perceptions of teaching as a career. Research in education, (62), 1+. Retrieved January 8, 2012, from Questia database: http://www.questia. com/PM.qst?a=o\&d=5035480817. 